ISSN 1392-3196 / e-ISSN 2335-8947

Zemdirbyste-Agriculture, vol. 101, No. 1 (2014), p. 75-78

DOI 10.13080/z-a.2014.101.010

\title{
Growing of leaf lettuce (Lactuca sativa $L$.) under high-pressure sodium lamps with supplemental blue, cyan and green LEDs
}

\author{
Ramunas SIRTAUTAS, Akvile VIRSILE, Giedre SAMUOLIENE, Ausra BRAZAITYTE, \\ Jurga MILIAUSKIENE, Sandra SAKALAUSKIENE, Pavelas DUCHOVSKIS \\ Institute of Horticulture, Lithuanian Research Centre for Agriculture and Forestry \\ Kauno 30, Babtai, Kaunas distr., Lithuania \\ E-mail: r.sirtautas@1sdi.lt
}

\begin{abstract}
The aim of this study was to evaluate the effect of combination of light-emitting diodes (LEDs) and high-pressure sodium (HPS) lighting on the growth of lettuce variety 'Multigreen 3' in a greenhouse. Supplemental blue light had an impact on the efficiency of photosynthetic performance in lettuce; however, different blue light wavelengths had uneven effect. The $470 \mathrm{~nm}$ light also had a positive impact on chlorophyll $a$ to $b$ ratio and higher specific leaf area (SLA) value and resulted in increased plant mass per leaf area. The overall growth performance, higher contents of soluble saccharides and higher growth rates, represented by net assimilation rate (NAR) value were determined in lettuce, cultivated under blue $455 \mathrm{~nm}$ light. The $505 \mathrm{~nm}$ light, being intermediate between blue and green wavelengths, had a significant positive effect on the content of photosynthetic pigments, higher NAR value thus also might be beneficial for supplemental baby leaf lettuce illumination. Green $535 \mathrm{~nm}$ light stimulated accumulation of soluble saccharides in lettuce and had controversial effect on photosynthetic pigment contents and assimilative indices, thus the evidence for the effect was inconclusive.
\end{abstract}

Key words: chlorophyll, greenhouse, growth analyses, LED, saccharides.

\section{Introduction}

Among various environmental factors, light is one of the most important variables affecting photosynthesis and its primary metabolites in plants (Kopsell, Kopsell, 2008; Perez-Balibrea et al., 2008). Through the photosensory system plants react to the physiologically active radiation within the range of 380-750 nm (Goins et al., 1997). Light quantity is often the limiting factor for plant growth and productivity in greenhouses. This is of relevant importance in the Northern countries, where natural irradiation level is low during autumn/winter season; therefore, the use of artificial lighting has been an important subject for investigation in the last century (Wheeler, 2008). Solid-state lighting, provided by lightemitting diodes (LEDs), has been potentially one of the biggest advancements in horticultural lighting over the last decades (Morrow, 2008). LED lighting systems have several unique advantages, including small size, relatively cool emitting surfaces, linearity between electrical input current and photon output and the ability to control spectral composition and flux in real time. These solid-state light sources are therefore ideal for use in plant lighting designs due to the possibility to select wavelengths corresponding to the plant photoreceptor absorption and to stimulate plant productivity or to influence plant morphology and metabolism (Bourget, 2008; Massa et al., 2008). The solidstate lighting technology, based on LEDs expanded the possibilities to analyze the effects of lighting parameters on physiological processes in plants (Samuolienè et al., 2011 $\mathrm{a} ; \mathrm{b})$. The LED lighting may be customized for the specific horticultural objectives and optimized for maximum production without wasting energy on nonproductive wavelengths (Tamulaitis et al., 2004; 2005).
The grow lights available for greenhouse lighting are fluorescent, high-pressure sodium and metal halide lamps that differentially affect plant growth, development and photomorphogenesis (Goins et al., 1997). High-pressure sodium lamps mostly emit an orange-red light, but they lack blue and green spectral components (Tennessen et al., 1994). Meanwhile, blue light is important and involved in a wide range of plant processes such as phototropism, photomorphogenesis, stomatal opening, leaf photosynthetic functioning, chloroplast development, chlorophyll formation and chemical composition of plants (Whitelam, Halliday, 2007; Morrow, 2008). Overall, there is a trend to higher mass production and photosynthetic capacity in a blue light-containing irradiance (Tennessen et al., 1994). The quantum yield of green light for photosynthesis is quite low. However, green light is efficiently absorbed and used for photosynthesis in inner canopy levels (Folta, Maruhnich, 2007; Terashima et al., 2009) and thus may stimulate growth in different plants (Kim et al., 2006) and affect the morphogenetic processes through phytochrome and cryptochrome activity.

Lettuce is one of the major crops cultivated worldwide in greenhouses during the winter/spring season, when natural illumination level is low. Its photosynthetic and metabolic performance is highly dependent on various light parameters, thus, lettuce seems to be a model crop widely studied for light quality response (Brazaityte et al., 2006; Wheeler, 2008). Therefore, the aim of this study was to evaluate the impact of highpressure sodium lamps with supplemental blue, cyan and green LEDs on the growth of lettuce variety 'Multigreen 3 ' in a greenhouse. 


\section{Materials and methods}

Chemicals. Calcium carbonate $\left(\mathrm{CaCO}_{3}\right)$ was obtained from "Lach-Ner" (Czech Republic). Sucrose, fructose, mannose and glucose were obtained from "SigmaAldrich" (Germany). Acetone was obtained from "Merck" (Germany). All standards and samples for high performance liquid chromatography (HPLC) were filtered through 0.25 $\mu \mathrm{m}$ nylon syringe filters ("Albet", Germany).

Growth conditions and plant material. The green baby leaf lettuce (Lactuca sativa L.) 'Multigreen 3' was grown to harvest time (about 22 days) in November 2010 in an industrial greenhouse of Institute of Horticulture, Lithuanian Research Centre of Agricultural and Forestry Science when photosynthetic photon flux density (PPFD) of natural solar irradiation was $\sim 80-120 \mu \mathrm{mol}$ $\mathrm{m}^{-2} \mathrm{~s}^{-1}$. High-pressure sodium (HPS) irradiance ("Son-T Agro", "Philips", USA) of $\sim 90 \mu \mathrm{mol} \mathrm{m}^{-2} \mathrm{~s}^{-1}$ PPFD was supplemented with $\sim 15 \mu \mathrm{mol} \mathrm{m} \mathrm{m}^{-2} \mathrm{~s}^{-1}$ flux of blue 455 $\mathrm{nm}$ and $470 \mathrm{~nm}$, cyan $505 \mathrm{~nm}$ and green $535 \mathrm{~nm}$ lightemitting diodes (LEDs). The surface area per light treatment was about $0.5 \mathrm{~m}^{2}$. Reference plants grew under natural illumination, supplemented with HPS lamps. The photoperiod of artificial irradiance was applied within $16 \mathrm{~h}$. PPFD level was measured using a photometerradiometer RF-100 ("Sonopan", Poland). Lettuce was sown in $120 \mathrm{ml}$ plastic vessels in peat substrate ( $\mathrm{pH} 5-6)$, 3 seeds per vessel. The amount of nutrients $\left(\mathrm{mg} \mathrm{l}^{-1}\right)$ in substrate was as follows: N 70, P 30, K 160, Ca 250, and $\mathrm{Mg} 50$. The day/night temperature in greenhouse was $20 / 16 \pm 3{ }^{\circ} \mathrm{C}$ and relative air humidity was $50-60 \%$.

Determination of soluble saccharides. Sucrose, fructose, mannose and glucose were analysed by HPLC method. The composite sample of lettuce leaves from five pots was used for analysis. About $1 \mathrm{~g}$ of fresh plant tissue was ground and diluted with $4 \mathrm{ml}+70^{\circ} \mathrm{C}$ analytical grade water. The extraction was carried out for $24 \mathrm{~h}$. The samples were filtered using cellulose acetate syringe filters (pore diameter $0.25 \mu \mathrm{m}$ ). Analyses were performed on a chromatograph "Shimadzu HPLC 10A" ("Shimadzu", Japan) with a refractive index detector RID 10A ("Shimadzu", Japan). Separation of soluble saccharides was performed on SC-1011 column $(300 \times$ $4.6 \mathrm{~mm}$ ) ("Shodex", Japan). Mobile phase - bi-distilled water; oven temperature was maintained at $+80^{\circ} \mathrm{C}$. The sensitivity of the HPLC method was established using a method validation protocol (ICH, 2005).

Determination of photosynthetic pigments. Fresh leaf tissue was ground with $0.5 \mathrm{~g} \mathrm{CaCO}_{3}$ diluted 1:250 with pure acetone and filtered through a cellulose filter. Chlorophyll $a, b$ and carotenoids were measured by specrophotometric method (Gavrilenko, Zigalova, 2003). The absorption was measured at $644 \mathrm{~nm}, 662 \mathrm{~nm}$ and 440.5 $\mathrm{nm}$, for chlorophyll $a, b$ and carotenoids, respectively.

Growth analyses. Five randomly selected lettuce plants were measured for each analysis. The leaf area was measured by a leaf area meter "WinDias" ("Delta-T Devices", UK). For the determination of dry mass, above-ground lettuce parts were dried in a drying oven ("Venticell-BMT", Czech Republic) at $+105^{\circ} \mathrm{C}$ for $24 \mathrm{~h}$. The net assimilation rate (NAR) of a plant was defined as its growth rate per unit leaf area per day $\left(\mathrm{g} \mathrm{cm}^{-2} \mathrm{~d}^{-1}\right)$. It can be calculated as: NAR $\left(\mathrm{g} \mathrm{cm}^{-2} \mathrm{~d}^{-1}\right)=\frac{1}{L A} \times \frac{d W}{d t}$, where LA is leaf area $\left(\mathrm{cm}^{2}\right)$ and $\frac{d W}{d t}-$ the change in plant dry mass per unit time. Specific leaf area (SLA) is the ratio of leaf area $\left(\mathrm{cm}^{2}\right)$ per plant to leaf dry weight.

Statistical analysis. Five biological and three analytical replications of soluble saccharides, photosynthetic pigments and physiological indices were performed for each treatment. Data are presented as mean \pm standard error (SE). Data analysis was performed using STATISTICA 7.0 for Windows, one-way analysis of variance $A N O V A$, the Fisher's LSD test from the control (HPS lighting) at the confidence level $p \leq 0.05$. Data was processed using software MS Excel (version 7.0).

\section{Results and discussion}

Our investigations revealed that blue, cyan and green LEDs, supplemental for the HPS irradiance in the greenhouse had significant effect on the contents of soluble saccharides (Table 1), photosynthetic pigments (Table 2) and assimilative indices (Table 3 ) in green baby leaf lettuce 'Multigreen 3'. The amount of soluble saccharides was found to be remarkably higher in lettuce, irradiated with the supplemental blue $455 \mathrm{~nm}$ light, as compared to other irradiance treatments. The amount of sucrose was determined 6 times higher, glucose 2.9 times, mannose 3.5 times and fructose 1.5 times higher in the lettuce, grown under supplemental $455 \mathrm{~nm}$ LEDs as compared to these, grown under sole HPS artificial irradiance. Supplemental $470 \mathrm{~nm}$ blue light, though being close to 455 $\mathrm{nm}$ blue light, had a less pronounced effect: the content of sucrose was found to be 1.8 times higher, glucose 2.3 times, mannose 3.3 times higher, as compared to soluble saccharide contents in lettuce without supplemental LED illumination. The $505 \mathrm{~nm}$ supplemental cyan LED light had the weakest stimulating effect on the accumulation of almost all soluble saccharides, when supplemental green $535 \mathrm{~nm}$ LED light had no significant effect on the contents of sucrose and fructose, but resulted in 3 times higher glucose and 5 times higher mannose concentration (Table 1). Saccharides are the main carbon and energy source in plants (Salerno, Curatti, 2003; Weber et al., 2005) and act as physiological signal affecting further metabolic processes, simultaneously affecting nutrient and gustatory properties of vegetable food (Koch, 2004).

Higher value of the chlorophyll $a$ to $b$ ratio usually represents better plant photosynthetic performance. However, the higher level of soluble saccharides in the leaves of baby leaf lettuce (Table 1), supplementary irradiated with blue $455 \mathrm{~nm}$ LED light match the reduced chlorophyll $a$ to $b$ ratio (Table 2). The decrease in exports of leaf sucrose and subsequent increase in leaf sucrose and sucrose cycling are responsible for photosynthesis down-regulation in plants (Moore et al., 1999).

In lettuce, supplementary irradiated with blue $470 \mathrm{~nm}$ light, the chlorophyll $a$ to $b$ ratio was found to be significantly higher. However, such an increase is rather due to the reduced chlorophyll $b$ concentration in leaves than the increased chlorophyll $a$ contents. Supplemental $505 \mathrm{~nm}$ light had the most pronounced effect on the photosynthetic pigment contents in lettuce: the concentrations of chlorophyll $a$, chlorophyll $b$ and carotenoids was determined to be $\sim 1.2$ times higher as compared to lettuce, grown without supplemental LED irradiance. The addition of green light may improve plant growth and photosynthesis by perceived specific photoreceptors and induces the pattern of investment of captured resources and the ability of the plant to capture further resources (Kim et al., 2006). However, supplemental green $535 \mathrm{~nm}$ light had no significant effect on chlorophylls. Only on the contents of carotenoid pigments significant effects were found.

Supplemental lighting also had effects on biometric lettuce parameters, determining differences in assimilative indices. SLA represents the mean leaf area 
Table 1. The content of soluble saccharides amount ( $\mathrm{mg} \mathrm{g}^{-1}$ fresh mass) in baby leaf lettuce 'Multigreen 3' under highpressure sodium (HPS) and supplemental light-emitting diode (LED) light

\begin{tabular}{|c|c|c|c|c|}
\hline \multicolumn{5}{|c|}{ Soluble saccharides } \\
\hline & sucrose & glucose & mannose & fructose \\
\hline HPS & $0.69 \pm 0.03$ & $2.49 \pm 0.04$ & $1.20 \pm 0.03$ & $0.23 \pm 0.04$ \\
\hline $\mathrm{HPS}+455 \mathrm{~nm}$ & $4.18 \pm 0.04 *$ & $7.32 \pm 0.02 *$ & $4.33 \pm 0.04 *$ & $0.36 \pm 0.03 *$ \\
\hline $\mathrm{HPS}+470 \mathrm{~nm}$ & $1.22 \pm 0.05^{*}$ & $5.70 \pm 0.03 *$ & $3.96 \pm 0.03 *$ & $0.28 \pm 0.01 *$ \\
\hline $\mathrm{HPS}+505 \mathrm{~nm}$ & $1.08 \pm 0.04^{*}$ & $3.47 \pm 0.04^{*}$ & $2.93 \pm 0.05^{*}$ & $0.28 \pm 0.03 *$ \\
\hline $\mathrm{HPS}+535 \mathrm{~nm}$ & $0.77 \pm 0.03$ & $7.50 \pm 0.04 *$ & $5.96 \pm 0.05 *$ & $0.29 \pm 0.04 *$ \\
\hline $\mathrm{LSD}_{05}$ & 0.18 & 0.21 & 0.12 & 0.02 \\
\hline
\end{tabular}

Note. ${ }^{*}$ - values (mean $\left.\pm \mathrm{SE}\right)$ in each column are significantly different $(p \leq 0.05)$ from HPS by Fisher's LSD test.

Table 2. The content of photosynthetic pigments ( $\mathrm{mg} \mathrm{g}^{-1}$ fresh mass) in baby leaf lettuce 'Multigreen 3' under highpressure sodium (HPS) and supplemental light-emitting diode (LED) light

\begin{tabular}{ccccc}
\hline \multicolumn{5}{c}{ Photosynthetic pigments } \\
\hline & chlorophyll $a$ to $b$ ratio & content of chlorophyll $a$ & content of chlorophyll $b$ & content of carotenoids \\
\hline HPS & $2.63 \pm 0.01$ & $0.71 \pm 0.01$ & $0.27 \pm 0.01$ & $0.24 \pm 0.02$ \\
HPS + 455 nm & $2.31 \pm 0.03$ & $0.67 \pm 0.04$ & $0.29 \pm 0.03$ & $0.24 \pm 0.03$ \\
HPS + 470 nm & $2.91 \pm 0.02^{*}$ & $0.70 \pm 0.02$ & $0.24 \pm 0.02$ & $0.24 \pm 0.01$ \\
HPS + 505 nm & $2.75 \pm 0.03$ & $0.88 \pm 0.04^{*}$ & $0.32 \pm 0.01^{*}$ & $0.29 \pm 0.03^{*}$ \\
HPS + 535 nm & $2.50 \pm 0.03$ & $0.60 \pm 0.03$ & $0.24 \pm 0.03$ & $0.20 \pm 0.03^{*}$ \\
\hline LSD $_{05}$ & 0.25 & 0.11 & 0.03 & 0.03 \\
\hline
\end{tabular}

Explanation under Table 1

per unit of leaf weight. Poorter (2002) observed that an increase in SLA implies that leaves invest less mass per unit area. Evaluating the supplemental lighting effect on baby leaf lettuce assimilation indices, the significant blue $470 \mathrm{~nm}$ light effect on SLA was observed (Table 3). Higher SLA value represents the thicker leaf or higher leaf mass investment per unit of leaf area (Poorter, 2002). Also higher SLA value in lettuce plants is associated with the altered ability to capture more light per unit mass and is more common in the shade-grown plants (Shipley, 2002).

Table 3. The assimilative indices in baby leaf lettuce 'Multigreen 3' under high-pressure sodium (HPS) and supplemental light-emitting diode (LED) light

\begin{tabular}{ccc}
\hline \multicolumn{3}{c}{ Assimilative indices } \\
\hline & $\begin{array}{c}\text { specific leaf area } \\
\text { (SLA) } \\
\mathrm{cm}^{2} \mathrm{~g}^{-1}\end{array}$ & $\begin{array}{c}\text { net assimilation rate } \\
\text { (NAR) } \\
\mathrm{g} \mathrm{cm}^{-2} \mathrm{~d}^{-1}\end{array}$ \\
\hline HPS & $796 \pm 74$ & $0.073 \pm 0.002$ \\
$\mathrm{HPS}+455 \mathrm{~nm}$ & $801 \pm 88$ & $0.084 \pm 0.005^{*}$ \\
$\mathrm{HPS}+470 \mathrm{~nm}$ & $981 \pm 105^{*}$ & $0.078 \pm 0.002$ \\
$\mathrm{HPS}+505 \mathrm{~nm}$ & $813 \pm 103$ & $0.084 \pm 0.008^{*}$ \\
HPS + 535 nm & $736 \pm 65$ & $0.086 \pm 0.003^{*}$ \\
\hline LSD $_{05}$ & 138 & 0.006 \\
\hline
\end{tabular}

Explanation under Table 1

The observed positive effect of artificial cyan $505 \mathrm{~nm}$ and green $535 \mathrm{~nm}$ light on the NAR, describing the growth rate per unit leaf area per day, indicates that the activity of photosynthetic system was accelerated by effective penetration of light of these wavelengths through the plant tissues. Plants absorb from $43 \%$ to $87 \%$ of the green light (Nishio, 2000) and use this energy for photosynthesis efficiently in lower canopy levels and deeper within leaf mesophyll (Folta, Maruhnich, 2007). Kim et al. (2006) reported the stimulating green light effect on lettuce photosynthesis; however, this trend was observed only at low green light levels: green light flux $>50 \%$ of total PPFD had the inhibiting effect. Different supplemental blue light wavelengths had different effects on growth rate: $455 \mathrm{~nm}$ supplemental blue light resulted in increased NAR value, when $470 \mathrm{~nm}$ light had no significant effect.

\section{Conclusion}

The combination of light-emitting diodes (LEDs) and high-pressure sodium (HPS) irradiance was efficient for the cultivation of 'Multigreen 3' variety of lettuce (Lactuca sativa L.) in a greenhouse. Supplemental blue light improved photosynthetic performance in lettuce; however, different blue light wavelengths had uneven effect. The $470 \mathrm{~nm}$ light resulted in higher chlorophyll $a$ to $b$ ratio and higher specific leaf area (SLA) value, and determined higher plant mass per leaf area. The overall growth performance, high contents of saccharides and higher growth rates, represented by net assimilation rate (NAR) value were determined in lettuce, cultivated under blue $455 \mathrm{~nm}$ light. The $505 \mathrm{~nm}$ light, being intermediate between blue and green wavelengths, had the most pronounced effect on photosynthetic pigment contents, higher NAR value and thus also might be beneficial for supplemental baby leaf lettuce illumination. Green 535 $\mathrm{nm}$ light stimulated soluble saccharide accumulation in lettuce, had inconsistent effect on photosynthetic pigment contents and assimilative indices, thus the evidence of the effect was inconclusive.

\section{Acknowledgements}

This research was funded by grant No. MIP$41 / 2010$ provided by the Research Council of Lithuania.

Received 19022013

Accepted 07112013

\section{References}

Bourget C. M. 2008. An introduction to light-emitting diodes. HortScience, 43 (7): 1944-1946

Brazaityte A., Ulinskaite R., Duchovskis P., Samuolienė G., Šikšnianienè J. B., Jankauskienè J., Śabajevienė G., Baranauskis K., Staniené G., Tamulaitis G., Bliznikas Z., Žukauskas A. 2006. Optimization of lighting spectrum for photosynthetic system and productivity of lettuce by using light-emitting diodes. Acta Horticulturae, 711: 183-188

Folta K. M., Maruhnich S. A. 2007. Green light: a signal to slow down or to stop. Journal of Experimental Botany, 58: 3099-3111 http://dx.doi.org/10.1093/jxb/erm130

Gavrilenko V. F., Zigalova T. V. 2003. Practice in photosynthesis. Moscow, Russia, 254 p. (in Russian) 
Goins G. D., Yorio N. C., Sanwo M. M., Brown C. S., Sager J. C. 1997. Photomorphogenesis, photosynthesis, and seed yield of wheat plants grown under red light-emitting diodes LEDs with and without artificial blue lighting. Journal of Exnerimental Botany, 48: 1407-1413 http://dx.doi.org/10.1093/jxb/48.7.1407

ICH. 2005. Harmonised tripartite guideline. Validation of analytical procedures: text and methodology Q2(R1). $<$ http://www.ich.org/> [accessed 2111 2013]

Kim H. H., Wheeler R. M., Sager J.C., Goins G. D. Norikane J. H. 2006. Evaluation of lettuce growth using supplemental green light with red and blue light-emitting diodes in a controlled environment - a review of research at Kennedy Space Center. Acta Horticulturae, 711: 111-119

Koch K. 2004. Sucrose metabolism: regulatory mechanisms and pivotal roles in sugar sensing and plant development. Current Opinion in Plant Biology, 7: 235-245 http://dx.doi.org/10.1016/j.pbi.2004.03.014

Kopsell D. A. Kopsell D. E. 2008. Genetic and environmental factors affecting plant lutein/zeaxanthin. Agro Food Industry Hi-Tech, 19: 44-46

Massa G. D., Kim H. H., Wheeler R. M., Mitchell C. A. 2008. Plant productivity in response to LED lighting. HortScience, 43 (7): 1951-1956

Moore B. D., Cheng S. H., Sims D., Seemann J. R. 1999. The biochemical and molecular basis for photosynthetic acclimation to elevated atmospheric $\mathrm{CO}_{2}$. Plant, Cell and Environment, 22: 567-582 http://dx.doi.org/10.1046/j.1365-3040.1999.00432.x

Morrow R. C. 2008. LED lighting in horticulture. HortScience, 43 (7): 7 1947-1950

Nishio J. N. 2000. Why are higher plants green? Evolution of the higher plant photosynthetic pigments complement. Plant. Cell and Environment. 23: 539-548 http://dx.doi.org/10.1046/j.1365-3040.2000.00563.x

Perez-Balibrea S., Moreno D. A. Garcia-Viguera C. 2008. Influence of light on health promoting phytochemicals of broccoli sprouts. Journal of the Science of Food and Agriculture. 88: 904-910 http://dx.doi.org/10.1002/jsfa.3169

Poorter H. 2002. Plant growth and carbon economy. Encyclopedia of Life Sciences. <http://www.science. poorter.eu/> [accessed 2012 2013]

Salerno G. L., Curatti L. 2003. Origin of sucrose metabolism in higher plants: when, how and why? Trends in Plant Science, 8: 63-69 http://dx.doi.org/10.1016/S1360-1385(02)00029-8
Samuolienė G., Urbonavičiūtė A., Brazaitytė A., Šabajevienė G., Sakalauskaite J. Duchovskis P. 2011 (a). The impact of LED illumination on antioxidant properties of sprouted seeds. Central Euronean Journal of Biologv. 6 (1): 68-74 http://dx.doi.org/10.2478/s11535-010-0094-1

Samuolienė G., Sirtautas R., Brazaityte A., Sakalauskaite J., Sakalauskienè S., Duchovskis P. 2011 (b). The impact of red and blue light-emitting diode illumination on radish physiological indices. Central European Journal of Biology, 6 (5): 821-828 http://dx.doi.org/10.2478/s11535-011-0059-z

Shipley B. 2002. Trade-ofts between net assimilation rate and specific leaf area in determining relative growth rate: relationship with daily irradiance. Functional Ecology, 16: $682-689$ http://dx.doi.org/10.1046/j.1365-2435.2002.00672.x

Tamulaitis G., Duchovskis P., Bliznikas Z., Breive K., Ulinskaite R., Brazaityte A., Novickovas A., Zukauskas A., Shur M. S. 2004. High-power LEDs for plant cultivation. SPIEProceedings, 5530: 165-173<http://spiedigitallibrary. org/index.aspx $>$ [accessed 1109 2013]

Tamulaitis G., Duchovskis P., Bliznikas Z., Breivè K., Ulinskaitė R., Brazaitytė A., Novičkovas A. Žukauskas A. 2005. High power light-emitting diode based facility for plant cultivation. Journal of Physics, D: Applied Physics, 38: $3182-3187$ http://dx.doi.org/10.1088/0022-3727/38/17/S20

Tennessen D. J., Singsaas E. L., Sharkey I. D. 1994. Lightemitting diodes as a light-source for photosynthesis research. Photosynthesis Research, 39: 85-92 http://dx.doi.org/10.1007/BF00027146

Terashima I., Fujita T., Inoue T., Chow W. S., Oguchi R. 2009. Green light drives leaf photosynthesis more efficiently than red light in strong white light: revisiting the enigmatic question of why leaves are green. Plant and Cell Physiology, 50: 684-697 http://dx.doi.org/10.1093/pcp/pcp034

Weber H., Borisjuk L., Wobus U. 2005. Molecular physiology of legume seed development, Annual Review of Plant Biologv. 56: 253-279 http://dx.doi.org/10.1146/annurev.arplant.56.032604.144201

Wheeler R. M. 2008. A historical background of plant lighting: an introduction to the workshop. HortScience, 43 (7): 1942-1943

Whitelam G., K. Hallidav. 2007. Light and plant development. Oxford, UK http://dx.doi.org/10.1002/9780470988893

ISSN 1392-3196 / e-ISSN 2335-8947

Zemdirbyste-Agriculture, vol. 101, No. 1 (2014), p. 75-78

DOI $10.13080 / \mathrm{z}-\mathrm{a} .2014 .101 .010$

\title{
Salotų auginimas po aukšto slègio natrio lempomis, šviesos spektrą papildžius mèlynais, ciano ir žaliais kietakūniais šviestukais
}

\author{
R. Sirtautas, A. Viršilè, G. Samuolienė, A. Brazaitytè, J. Miliauskienė, S. Sakalauskienė, P. Duchovskis \\ Lietuvos agrarinių ir miškų mokslų centro Sodininkystès ir daržininkystès institutas
}

\section{Santrauka}

Tyrimo tikslas - įvertinti aukšto slègio natrio lempų ir papildomų mėlynų, ciano ir žalių kietakūnių šviestukų apšvietimo ịtaką veislès 'Multigreen 3' sèjamosios salotos (Lactuca sativa L.) augimui šiltnamyje.

Papildoma mèlyna šviesa turejjo įtakos fotosintezės efektyvumui salotose, bet skirtingos mėlynos šviesos bangos turèjo nevienodą poveikį. $470 \mathrm{~nm}$ šviesa taip pat turejjo teigiamą įtaką chlorofilo $a$ ir $b$ santykiui bei specifiniam lapu plotui, lèmé didesnị augalo biomasès ir lapų ploto santykị. Augimo efektyvumas, didesnis tirpių angliavandenių kiekis ir augimo greitis, kuris nusakomas santykiniu augimo greičiu, nustatyti po mèlynais $455 \mathrm{~nm}$ LED. 505 $\mathrm{nm}$ šviesa, kuri yra tarp mėlynos ir žalios šviesos, turèjo žymią teigiamą ịtaką fotosintetinių pigmentų kiekiui. Padidèjęs santykinis augimo greitis taip pat buvo sąlygotas salotų apšvietimo. Žalia $535 \mathrm{~nm}$ šviesa stimuliavo angliavandenių kaupimąsi salotose ir turèjo nevienareikšmę įtaką fotosintetiniams pigmentams bei asimiliaciniams indeksams. Tyrimo rezultatai kol kas nepatvirtino žalios šviesos įtakos.

Reikšminiai žodžiai: angliavandeniai, augimo analizės, chlorofilai, kietakūniai šviestukai, šiltnamis. 